\title{
Bioconversion of isoflavones glycoside to aglycone during edamame (Glycine max) soygurt production using Streptococcus thermophillus FNCC40, Lactobacillus delbrueckii FNCC41, and L. plantarum FNCC26
}

\author{
NOVILA SANTI LOVABYTA ${ }^{\mathbf{1}}$, JAY JAYUS ${ }^{2,4, \bullet}$, ARI SATIA NUGRAHA ${ }^{3,5}$ \\ ${ }^{1}$ Graduate School of Biotechnology, Universitas Jember. Jl. Kalimantan 37, Kampus Tegalboto, Jember 68121, East Java, Indonesia \\ ${ }^{2}$ Center of Excellent for Industrial Plant Biotechnology, Universitas Jember. Jl. Kalimantan 37, Kampus Tegalboto, Jember 68121, East Java, Indonesia \\ ${ }^{3}$ Center for Development of Advanced Science and Technology, Universitas Jember. Jl. Kalimantan 37, Kampus Tegalboto, Jember 68121, East Java, \\ Indonesia \\ ${ }^{4}$ Department of Agricultural Product Technology, Faculty of Agricultural Technology, Universitas Jember. Jl. Kalimantan 37, Kampus Tegalboto, \\ Jember 68121, East Java, Indonesia. Tel.: +62-331-334270, 330224, Fax.: +62-331-333147, `email: jayus.ftp@unej.ac.id \\ ${ }^{5}$ Drug Utilisation and Discovery Research Group, Faculty of Pharmacy, Universitas Jember. Jl. Kalimantan 37, Kampus Tegalboto, Jember 68121, East \\ Java, Indonesia
}

Manuscript received: 9 December 2019. Revision accepted: 8 March 2020.

\begin{abstract}
Lovabyta NS, Jayus J, Nugraha AS. 2020. Bioconversion of isoflavones glycoside to aglycone during edamame (Glycine max) soygurt production using Streptococcus thermophillus FNCC40, Lactobacillus delbrueckii FNCC41, and L. plantarum FNCC26. Biodiversitas 21: 1358-1364. Due to its strong radical-scavenging and antioxidative activity, isoflavones in soybeans have received great attention for the development of functional foods. This study focused on bioconversion of isoflavones glycoside into its aglycone form of edamame green soymilk fermented with three lactic acid bacteria (LAB), i.e., S. thermophilus FNCC40, L. bulgaricus FNCC41, and L. plantarum FNCC26 to produce soygurt. Green soymilk was fermented with $6 \%(\mathrm{v} / \mathrm{v})$ of LABs as a starter culture for 24 hours at $37^{\circ} \mathrm{C}$. Its antioxidative activity were measured using DPPH free radical scavenging activity method. Daidzein and genistein released during fermentation were fractionated using HPLC and detected further by LCMS to confirm the presence of these two substances. The results showed that the population density of starter culture in green soymilk reached $10^{9} \mathrm{CFU} / \mathrm{mL}$, and the $\mathrm{pH}$ decrease from 6.8 to 3.5 . All LABs cultures used in the fermentation process were able to produce free aglycone, releasing more daidzein and genistein. Increasing daidzein and genistein content in soygurt results in increasing antioxidative activity. The highest antioxidative activity $\left(\mathrm{IC}_{50}=\right.$ $41.01 \mathrm{mg} / \mathrm{mL}$ ) was found in the soygurt fermented with $S$. thermophilus FNCC40. This finding indicates that S. thermophilus FNCC40, L. bulgaricus FNCC41, and L. plantarum FNCC26 are potential as an effective starter culture to produce a soygurt with good antioxidant activity.
\end{abstract}

Keywords: Aglycone, antioxidant, bioconversion, isoflavone, soygurt

\section{INTRODUCTION}

Demand for soy products as functional food was increasing, mainly related to the content and antioxidative activities that related to its isoflavones structures (Rigo et al. 2015). Several studies showed that the fermentation process could increase the content of bioactive compounds in soy products with health benefits such as preventing degenerative diseases, strengthening the immune system of the human body, antioxidant (Sirilun et al. 2017b), antiinflammatory agents on skin cells exposed to UV-B irradiation (Iovine et al. 2011), anti-hypercholesterolemia (Kobayashi et al. 2014), antidiabetic (Hasim et al. 2015), preventing osteoporosis, heart disease (Jooyandeh 2011), breast cancer (Campos and Matos 2010) and prostate cancer (Medjakovic et al. 2010), increase mineral bioavailability, produce vitamin B complex (Rekha and Vijayalakshmi 2010) and vitamin B12 (Molina et al. 2012). Furthermore, soy-based food products are a very good source of nutrients such as protein, omega-3 unsaturated fatty acids, vitamins, and minerals (Rigo et al. 2015). Soybean or edamame does not contain cholesterol and lactose as found in dairy-based products, so it is safe for hypercholesterolemia and lactose intolerance people (Mebrahtu et al. 2004).

Edamame is one type of Indonesian green soybean that has been exported to several countries, including Japan, Taiwan, China, Korea (Hammond and Jez 2011), Australia (James 2007), Europe, and America (Mentreddy et al. 2002). It has been considered as a health-promoting food with low carbohydrate and fat content, high protein content $(10 \%)$ and dietary fiber (16\%), and contains more isoflavones (48.95 mg/100 g) compared to ordinary soybean (34.39 $\mathrm{mg} / 100 \mathrm{~g}$ ) (U.S. Department of Agriculture 2008). However, isoflavones in edamame or other soybeans are predominantly available in the form of glycosides in nature (Ko 2014), such as daidzin and genistin (Rigo et al. 2015). Many studies reported that isoflavones in the form of its aglycone (not binding to sugar) have a higher functional effect and absorbed faster than the glycoside form (Islam et al. 2014). Its glycoside forms have large hydrophilic structures that are not easily absorbed across the enterocytes or intestinal absorptive cells (Rafii 2015). One method to increase the aglycone content in fermented soy products or better known as soygurt can be done through enzymatic hydrolysis by microorganisms as starter culture (Molina et 
al. 2012) specifically using lactic acid bacteria (LAB) (Peng and Guo 2015) or probiotic strains (Li et al. 2012). During the fermentation process, LABs were able to produce $\beta$-glucosidase, which can convert isoflavones glycosides into aglycone by degrading the glycosidic linkage of isoflavones (Song et al. 2011; Hasim et al. 2015). Enzymes will break glucose groups attached to the oxygen atom (glycoside) of isoflavones, and the position of sugars will be replaced by hydrogen atoms to form aglycone isoflavones (Hasim et al. 2015).

Besides its ability to convert isoflavones, LABs culture can influence the product quality and sensory properties such as taste, texture, flavor, and chemical content or enhance acidification ( $\mathrm{Li}$ et al. 2017). LABs starter culture such as $S$. thermophilus, L. bulgaricus, and L. plantarum have been used widely to produce cow's milk yogurt (Baglio 2014) and to ferment soymilk to produce soygurt, due to their high $\beta$-glucosidase activity during their growth (Rekha and Vijayalakshmi 2010). However, not all LABs can secrete $\beta$-glucosidase into their media, and some of them are bound to cells and are not able to degrade the available isoflavones in soymilk (Choi et al. 2002). The efficiency of LABs in converting soybean isoflavones glycoside to its aglycone form was also varies depending on the LABs strain and the soybean variety used. For instance, Bifidobacterium animalis $\mathrm{Bb} 12$ exhibited a higher ability in the conversion of daidzein compared to $B$. animalis V9 when grown in the same soybean variant $(\mathrm{Li}$ et al. 2012).

Meanwhile, Streptococcus thermophilus S10 has been reported as the strain which has the highest activity for converting isoflavones glycoside in black soybean (Lee et al. 2015). However, in other varieties of soybean, Lactobacillus acidophilus B4496 (Rekha and Vijayalakshmi 2010) and L. paraplantarum KM (Chun et al. 2007) have the highest activity on converting daidzein. The study is needed to examine the ability of each strain of LABs in converting isoflavones glycoside to its aglycone form in each variety of soybeans to find the most efficient culture. Since the viability and ability of LABs in producing $\beta$-glucosidase may differ depending on the culture condition and the soybean variety used, therefore this study was conducted to determine the starter culture potency and ability of $S$. thermophilus FNCC40, $L$. bulgaricus FNCC41, and L. plantarum FNCC26 to convert isoflavones of edamame green soymilk and to enhance antioxidative substance during the soygurt production.

\section{MATERIALS AND METHODS}

\section{Materials and reagents}

Edamame (green vegetable soybean) was obtained from Mitra Tani 27 Co. Ltd., as edamame producing company in Jember, East Java, Indonesia. Broth and agar media of de Mann Rogosa Sharpe (MRS) (Merck, USA) were used to culture and determine the total counts of LABs. Solvents for isoflavone extraction were n-Hexane, ethyl acetate, and methanol (Merck, USA). Acetonitrile (Merck, USA) and sterile water (WIDA $\mathrm{WI}^{\mathrm{tm}}$ Unicap) were used for HPLC analysis and a mobile phase of isoflavone elution. The determination of free radical scavenging activities was using 2,2-diphenyl-1-picrylhydrazyl (Sigma-Aldrich, USA) as a synthetic substrate.

\section{Microorganisms}

Streptococcus thermophillus FNCC40 (ST), L. delbrueckii subspecies bulgaricus FNCC41 (LB), and $L$. plantarum FNCC26 (LP) were obtained from FNCC (Food and Nutrition Culture Collection), the University of Gadjah Mada, Yogyakarta, Indonesia. The LABs were cultured in MRS broth media and incubated at $37^{\circ} \mathrm{C}$ for $24 \mathrm{~h}$ (Prasad and Shah 2012).

\section{Soymilk preparation}

Edamame (100 g) was washed twice with water and soaked in distilled water for eight hours. After boiling at $100^{\circ} \mathrm{C}$ for $3 \mathrm{~min}$, the beans were then grounded using a food processor for $2 \mathrm{~min}$ with the ratio of edamame and water 1:3 (w/v). The slurry was filtered through a cotton sheet to produce soymilk. After skim milk and sugar (5\%, w/v) addition, the green soymilk was pasteurized at $95^{\circ} \mathrm{C}$ for $5 \mathrm{~min}$, then cooled to $\pm 40^{\circ} \mathrm{C}$ (Peng and Guo 2015).

\section{Soymilk fermentation}

Starter cultures for the edamame green soymilk fermentation were prepared by inoculating each LAB into pasteurized green soymilk (1:9, v/v) aseptically and incubated at $37^{\circ} \mathrm{C}$ for $24 \mathrm{~h}$. It was the optimal fermentation time to produced soygurt with a high amount of probiotics (Wei et al. 2007) and enzyme activity (Rekha and Vijayalakshmi 2010). According to Peng and Guo (2015), green soymilk was fermented with $6 \%$ of the starter inoculation into pasteurized green soymilk and incubated under the same conditions (Peng and Guo 2015) The number of cells at the beginning of fermentation were $\pm 10^{5}$ $\mathrm{CFU} / \mathrm{mL}$. The green soymilk was individually fermented with $S$. thermophilus FNCC40 (ST), L. bulgaricus FNCC41 (LB), and L. plantarum FNCC26 (LP).

\section{Determination of $\mathbf{p H}$}

The acidity level of three samples with a different culture that is potentially producing several acids (Sirilun et al. 2017a) was measured using a pH meter. This measurement was repeated three times.

\section{Enumeration of viable lactic acid bacteria (LAB)}

The total number of lactic acid was calculated using the method of Lee et al. (2015) with some minor modifications. The growth of LABs in the samples was measured using MRS (de Man Rogosa Sharpe) agar media after incubation at $37^{\circ} \mathrm{C}$ for $24 \mathrm{~h}$. The samples were serially diluted at $10^{-7}, 10^{-8}$, and $10^{-9}$ using physiological solutions $(\mathrm{NaCl}, 0.85 \% \mathrm{w} / \mathrm{v})$. The presence of LABs was determined by the appearance of a clear zone on the media surrounding the colony due to the reaction of LABs acid with $\mathrm{CaCO}_{3}$ $(1 \% \mathrm{w} / \mathrm{v})$. Observations were conducted after 24 hours fermentation. Colonies that are able to form clear zones were recorded dan counted in terms of colony form unit $(\mathrm{CFU}) / \mathrm{mL}$ sample. 


\section{Isoflavone extraction}

The freeze-dried unfermented and fermented green soymilk $(0.5 \mathrm{~g})$ was treated with $\mathrm{n}$-hexane $(1 \mathrm{~mL})$ to remove fat. Samples were homogenized using vortex for 1 minute, followed by sonication at $50-60 \mathrm{~Hz}$ for 20 minutes before centrifugation at $10,000 \mathrm{rpm}$ for 10 minutes at $25^{\circ} \mathrm{C}$. The hexane layer was removed, and ethyl acetate $(1 \mathrm{~mL})$ was added, followed by homogenization, sonication, and centrifugation under the same conditions as the previous treatment. The ethyl acetate layer was collected and put into a microtube and vacuum dried subsequently (Hasim et al. 2015).

\section{HPLC and MS analysis of isoflavones}

Isoflavone extract in each microtube was dissolved in $80 \%$ methanol $(1 \mathrm{mg} / 10 \mu \mathrm{L})$ and filtered through a $0.45 \mu \mathrm{m}$ HPLC membrane filter. Separation of isoflavones was carried out in HPLC CECIL Q4 Adept and C18 columns at $254 \mathrm{~nm}$ wavelength for 45 minutes. Sterile distilled water and acetonitrile were used as the developing solvents, where the gradient of the eluent was adjusted, as shown in Figure 1. The flow rate of the mobile phase was adjusted at $1 \mathrm{~mL} / \mathrm{min}$ following the method of Montero et al. (2018), and the column temperature was kept constant at $25^{\circ} \mathrm{C}$. The increase of isoflavones was calculated based on the relative amount of peak area before and after fermentation. The fractions were collected for further analysis using Mass Spectrometry (MS) (Boue et al. 2003).

\section{DPPH free radical scavenging assay (RSA)}

The antioxidant activity in terms of radical scavenging activity of the isoflavones extract was analyzed by DPPH (1,1-diphenyl-2-picrylhydrazyl) method, according to Lee et al. (2015) with some minor modifications. Isoflavone extract was diluted using methanol into serial concentration of 10 , 20, 30, 40, 50 and $60 \mathrm{mg} / \mathrm{mL}$. Each diluted mixture was vortexed for 1 minute and then sonicated $(50-60 \mathrm{~Hz})$ for 10 minutes, followed by centrifugation for 10 minutes at $10,000 \mathrm{rpm}$ at $25^{\circ} \mathrm{C}$. Fifty $\mu \mathrm{L}$ of diluted isoflavone extract and $250 \mu \mathrm{L}$ DPPH solution $(75 \mu \mathrm{M}$ in methanol) were vortexed for 1 minute and incubated for 30 minutes in dark conditions. The absorbances of the solution were measured at $517 \mathrm{~nm}$. Serial concentrations of the samples were made to obtain a linear equation of sample concentration against the percentage of inhibition (Figure 6). The $\mathrm{IC}_{50}$ value of the sample was determined based on the sample concentration that can scavenge 50\% of free radicals DPPH. The percentage of RSA was calculated using this following equation:

\%RSA = (Blank Absorbance-Sample Absorbance) $/$ Blank Absorbance x 100\%

\section{RESULTS AND DISCUSSION}

\section{LABs growth and $\mathrm{pH}$ changes in green soymilk during the fermentation process}

The LABs grown in edamame green soymilk has rapid growth within the first 24 hours of fermentation, as presented in Figure 2. The average number of LAB in all cultures in MRSA media reached $10^{9} \mathrm{CFU} / \mathrm{mL}$ at $37^{\circ} \mathrm{C}$, which meets the minimum requirements as a probiotic $\left(10^{6}-10^{9} \mathrm{CFU} / \mathrm{g}\right)$ that provide beneficial health effects as recommended by most countries (Arena et al. 2015). The highest number of LABs was observed at the soygurt inoculated with $S$. thermophillus FNCC40 as strain (1.85 x $\left.10^{9} \mathrm{CFU} / \mathrm{mL}\right)$, followed by $L$. bulgaricus FNCC41 $(1.35 \mathrm{x}$ $\left.10^{9} \mathrm{CFU} / \mathrm{mL}\right)$ and L. plantarum FNCC26 $\left(0.67 \times 10^{9}\right.$ $\mathrm{CFU} / \mathrm{mL}$ ).

Several studies have reported that LABs have high cell viability as probiotics. Lactobacillus bulgaricus CFR2028 and Lactobacillus plantarum B4495 reached 7.75 and 7.57 $\log 10 \mathrm{CFU} / \mathrm{mL}$ in soymilk after $12 \mathrm{~h}$ fermentation (Rekha and Vijayalakshmi 2010). Lee et al. (2015) reported that Streptococcus thermophilus $\mathrm{S} 10$ reached $9 \log \mathrm{CFU} / \mathrm{mL}$ in black soymilk during $24 \mathrm{~h}$ fermentation. The high viability of LABs to grow in soymilk is maintained by their proteolytic activity (Shah 2000; Donkor et al. 2007), that released during their growth to cleave protein into free amino acids to support their growth.

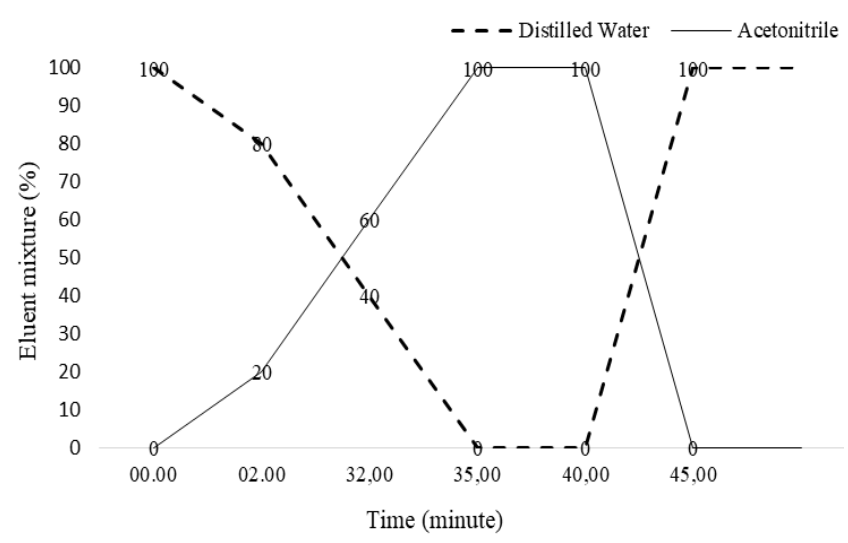

Figure 1. Elution profile of the eluent mixture for the isoflavones separation on HPLC

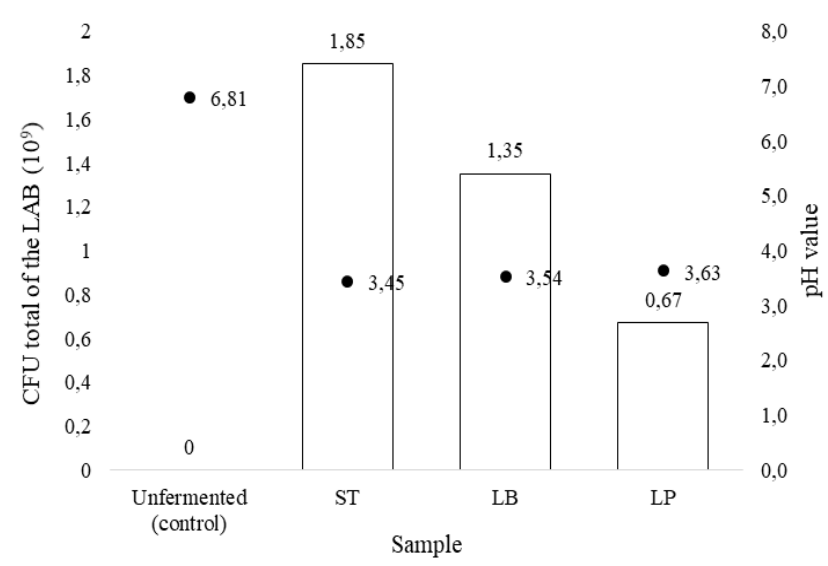

Figure 2. The CFU total of LAB ( $\square$ ) and $\mathrm{pH}$ values $(\bullet)$ of edamame green soymilk before and after $24 \mathrm{~h}$ fermentation using ST (S. thermophilus FNCC40); LB (L. bulgaricus FNCC41); and LP (L. plantarum FNCC26) 
The high viability of $S$. thermophilus, L. bulgaricus, and $L$. plantarum as probiotic is important because they have to survive in the gastrointestinal tract. The percentage of LABs survival within the gastrointestinal tract are varied depending on the strain (Arena et al. 2015). Probiotics provide beneficial health effects, such as maintaining colon microbial balance, eliminating potentially toxic foods, preventing intestinal infections, reducing inflammation, and reducing blood cholesterol (Kobayashi et al. 2014).

The fermentation of soymilk into a soygurt is a slow acidification process (Peng and Guo 2015). Coagulation of soymilk occurs when the isoelectric point of the protein is reached after the production of acid by the starter culture (Baglio 2014). Therefore, the organoleptic index of yogurt acidity is an important factor. LABs use the organic ingredients as an energy source and excrete by-products such as lactic acid, acetic acid, or other organic acids (Isa and Razavi 2017). The presence of acid results in decreased $\mathrm{pH}$ value during the fermentation, as presented in Figure 2. The $\mathrm{pH}$ values of green soymilk were decreased from 6.8 to 3.5 after $24 \mathrm{~h}$ fermentation process. The lower the $\mathrm{pH}$ values, the higher the number of cells detected, as shown in soygurt inoculated with ST. Acidity is an important factor in producing high-quality fermented soymilk (Lee et al. 2015).

\section{Changes in isoflavone contents}

The results on the chromatogram (Figure 5) showed chromatogram alignment of unfermented and fermented soygurt shows two peaks superimposed at the same position representing the occurrence of the secondary metabolites daidzein and genistein at e retention time of 12 and 14 minutes as confirmed by LC-MS spectra and their chemical structure (Figure 3 and 4). The protocol was successfully developed to isolate and characterize the isoflavone component formed during the fermentation of LABs, as was done by Montero et al. (2018).

The relative amount of daidzein and genistein released from different LABs cultures were vary depending on the culture used. The results showed that edamame green soymilk fermented by any of the selected LABs have higher daidzein and genistein compared to that of nonfermented, as can be seen in HPLC chromatogram (Figure 5). The results from three strains of LABs, showed that the highest daidzein (up to 369.2 mAs) was detected in LB soygurt, while the highest genistein (up to $480.5 \mathrm{mAs}$ ) was observed in ST soygurt. The higher daidzein and genistein released in the culture of fermented soygurt may be caused by the more $\beta$-glucosidase produced by LABs strain used. However, the properties of $\beta$-glucosidase produced by the LABs used in this study were not yet characterized. The enzyme may specifically hydrolyze daidzin and or genistin as the substrate, but this may not be the case since the substrate specificity of $\beta$-glucosidases are diverse, not only the pseudo-sugar of flavonoids glycoside but also any other glycoside including artificial aryl glycosides and glycosphingolipids (Ketudat and Cairns 2010). Tsuda and Shibata (2017) also reported the $\beta$-glucosidase activity from LABs strains were able to hydrolyze cellobiose, while $\beta$-glucosidases from $L$. plantarum have been reported to hydrolyzed oligosaccharide and or polysaccharide of jackfruit seed (Jayus et al. 2016; Jayus et al. 2018).

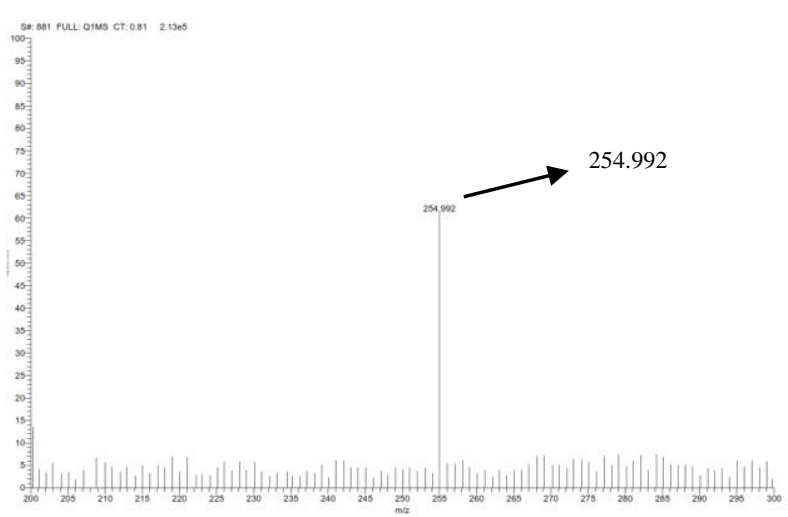

A

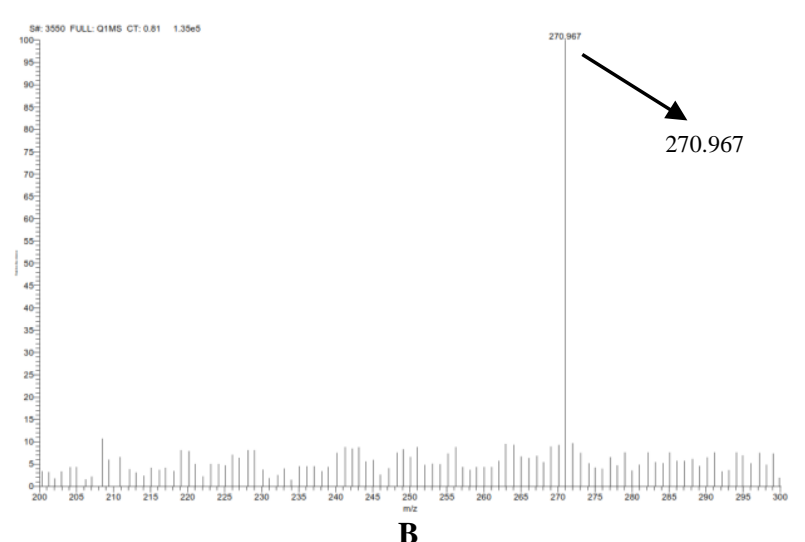

B

Figure 3. MS spectra of the fraction peak of fermented edamame green soymilk representing daidzein (A) and genistein (B)<smiles>O=c1c(-c2ccc(O)cc2)coc2ccc(O)cc12</smiles>

Chemical Formula: $\mathrm{C}_{15} \mathrm{H}_{10} \mathrm{O}_{4}$

Exact Mass: 254,06

Molecular Weight: 254,24

A<smiles>O=c1c(-c2ccc(O)cc2)coc2cc(O)cc(O)c12</smiles>

Chemical Formula: $\mathrm{C}_{15} \mathrm{H}_{10} \mathrm{O}_{5}$ Exact Mass: 270,05

Molecular Weight: 270,24

B

Figure 4. Chemical structure of daidzein (A) and genistein (B) (Montero et al. 2018) 


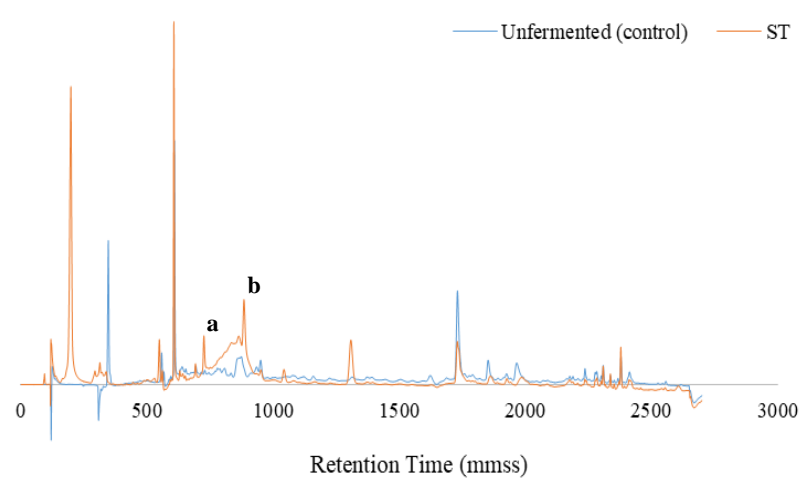

A

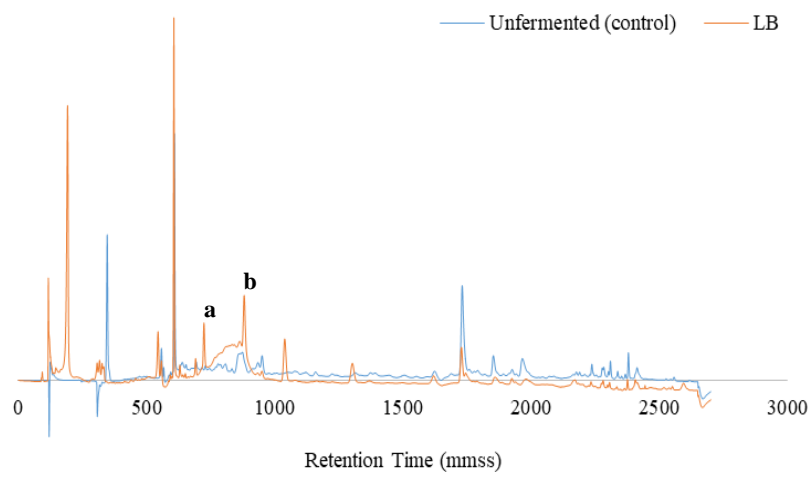

B

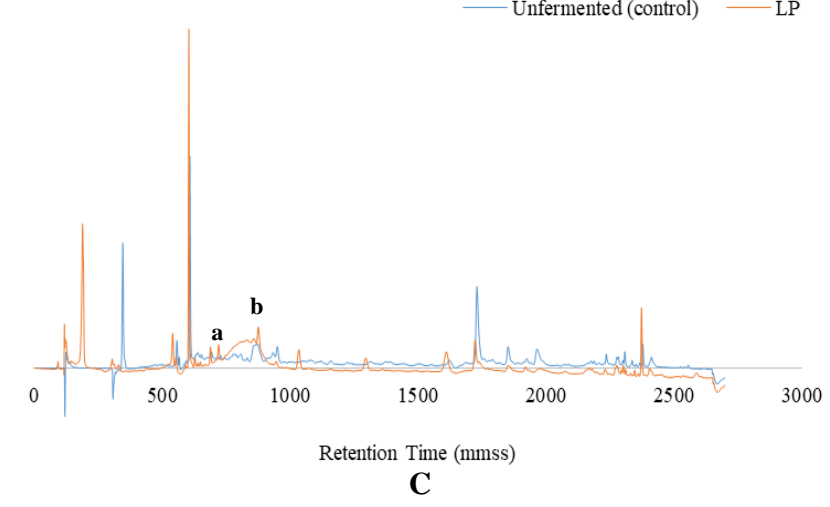

Figure 5. HPLC chromatogram of fermented green soymilk by ST (S. thermophilus FNCC40) (A), LB (L. bulgaricus FNCC41) (B), and LP (L. plantarum FNCC26) (C) compared to unfermented green soymilk as control

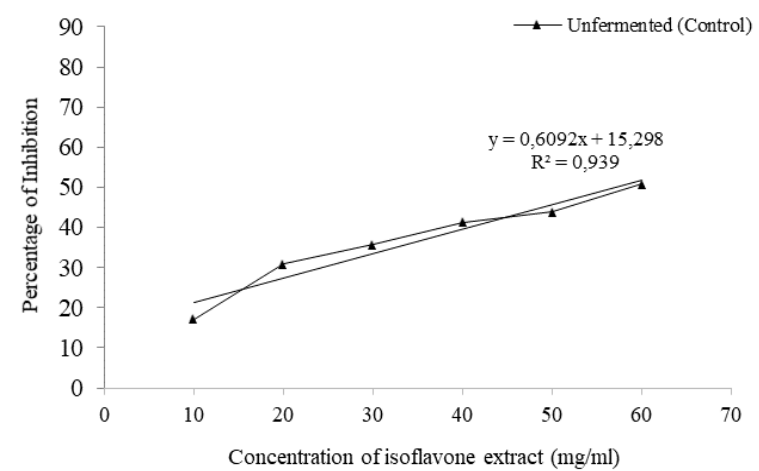

A

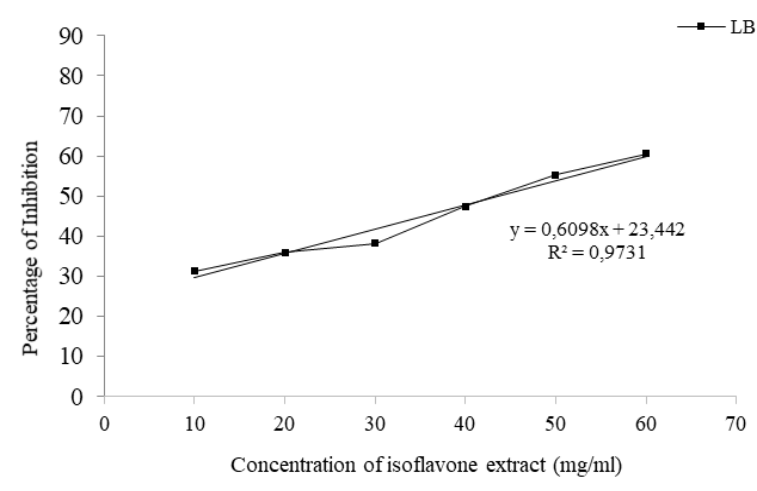

C

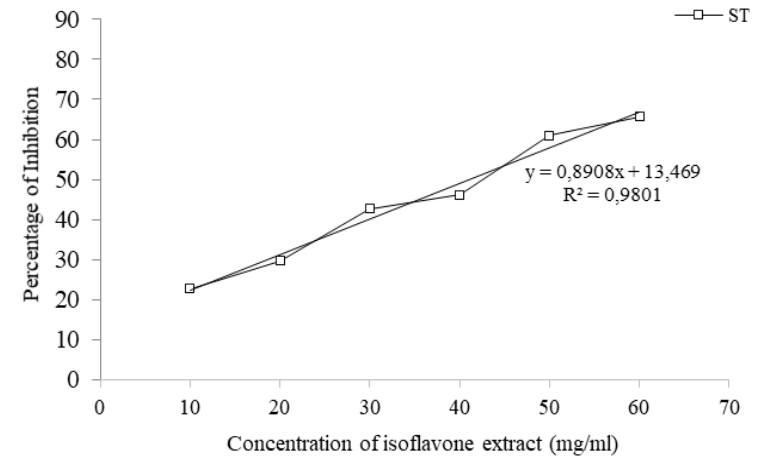

B

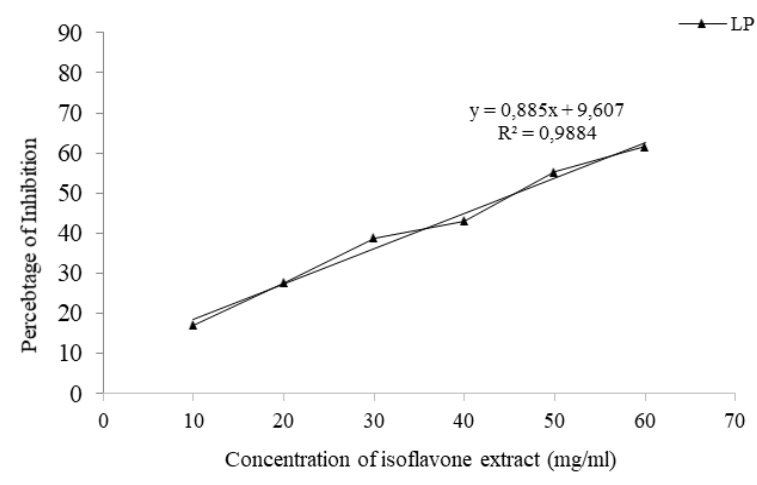

D

Figure 6. The linear curve of DPPH free radical inhibition of unfermented green soymilk (A) and fermented green soymilk using ST (S. thermophilus FNCC40) (B), LB (L. bulgaricus FNCC41) (C), and LP (L. plantarum FNCC26) (D) 
Table 1. The relative amount of daidzein and genistein of fermented green soymilk and its antioxidant activity

\begin{tabular}{lccccc}
\hline \multirow{2}{*}{ Culture strain } & \multicolumn{2}{c}{ The area of fraction peak (mAs) } & \multicolumn{2}{c}{ Relative amount (times) } & \multirow{2}{*}{$\begin{array}{c}\text { Antioxidant activity } \\
\text { (IC }\end{array}$} \\
\cline { 2 - 5 } Do $\mathbf{m g} / \mathbf{m L})$ & Daidzein & Genistein & Daidzein & Genistein & 56.96 \\
Unfermented (Control) & 26.7 & 133.4 & 1 & 1 & 41.01 \\
S. thermophilus FNCC40 & 252.5 & 480.5 & 9.5 & 3.6 & 43.55 \\
L. bulgaricus FNCC41 & 369.2 & 459.9 & 13.8 & 3.4 & 45.64 \\
L. plantarum FNCC26 & 157.4 & 174.5 & 5.9 & 1.3 & \\
\hline
\end{tabular}

In other studies, Rekha and Vijayalakshmi (2010) reported that genistein concentration $(25.01 \mathrm{mg} / 100 \mathrm{~mL})$ was higher than daidzein $(6.23 \mathrm{mg} / 100 \mathrm{~mL})$ in fermented green soymilk using probiotic bacteria. It is also detected in $S$. thermophilus S10 fermented soymilk, that contains more genistein $(0.32 \mathrm{mg} / \mathrm{g})$ than daidzein $(0.25 \mathrm{mg} / \mathrm{g})$ (Lee et al. 2005). Moreover, Fu and Zhang (2013) reported that higher genistein concentration than daidzein in a fermented chickpea yogurt using L. bulgaricus and S. thermophilus might be caused by $\beta$-glucosidase produced by LABs strain has more affinity to genistin than daidzin, or the amount of genistein in soybean is higher than daidzin. Li et al. (2012) reported that the amount of genistein in soybean is higher $(105.57 \pm 4.20 \mu \mathrm{g} / \mathrm{g})$ than daidzin $(73.75 \pm 3.44 \mu \mathrm{g} / \mathrm{g})$

Several LABs release $\beta$-glucosidases in soymilk media and successfully convert isoflavones glycoside to daidzein and genistein during the soybean fermentation process. A study by Choi et al. (2002) showed that $\beta$-glucosidases produced by LABs could not convert isoflavones glycoside when they were grown in culture media without soymilk. It might be due to $\beta$-glucosidases from LABs that are induced by a certain substance in soymilk. The hydrolyzes efficiency of $\beta$-glucosidases produced by LABs also varies depending on the strain used. A study by Chun et al. (2007) showed that $L$. paraplantarum KM was able to degrade $100 \%$ of genistein and $90 \%$ of daidzein, while Streptococcus salivarius HM was able to hydrolyze genistein and daidzein as much as $21 \%$ and $45 \%$ respectively within six $h$ of the fermentation process. The percentage of daidzein and genistein released by LABs is differs depending on the strain used. L. bulgaricus CFR2028 was capable of producing higher daidzein and genistein than that of $L$. plantarum B4495 (Rekha and Vijayalakshmi 2010). Several strains of L. plantarum, such as JAB2001 and FM2003, have more capability in converting daidzein, but L. plantarum WAB01 cannot degrade daidzein (Tsuda and Shibata 2017).

\section{DPPH free radical scavenging activity (RSA)}

The $\mathrm{IC}_{50}$ values of soygurt produced by different starter cultures were varied. The antioxidant activity of unfermented green soymilk was lower compared to fermented green soymilk (soygurt). The increased antioxidant activity in soygurt is due to the presence of aglycones such as daidzein and genistein. The highest antioxidative activity (the lowest $\mathrm{IC}_{50}$ value is 41.01 $\mathrm{mg} / \mathrm{mL}$ ) was observed in soygurt fermented with ST culture (Figure 6 and Table 1), which also had the highest content of genistein (480.5 mAs). A similar finding was reported by Lee et al. (2015) that black soymilk fermented with S. thermophilus S10 had higher aglycones (genistein and daidzein) content also had higher antioxidant activity. A study by Cheng et al. (2013) showed that the antioxidant activity of soybean samples was related to the content of genistein and daidzein.

Soyghurt fermented with LB culture had lower antioxidant activity (IC50 value $=43.55 \mathrm{mg} / \mathrm{mL}$ ) compared to ST soyghurt despite the highest daidzein content (369.2 $\mathrm{mAs}$ ). It may indicate that genistein plays an important role in the antioxidative activity of soygurt. Genistein contributes more to antioxidative activity, since the soyghurt fermented with ST culture possess the highest level of genistein, and also exhibit the highest antioxidant activity. The daidzein may have less effect compared to genistein on antioxidant activity. Choi and Kim (2014) reported that daidzein possesses lower antioxidant activities compared to its metabolism product such as $O$-desmethylangolensin (O-DMA) and equol. Genistein as an antioxidant can stabilize free radicals, affect the gene expression of catalase and superoxide dismutase, and hindering the auxiliary oxidant, such as hypochlorous acid or hydrogen peroxide. Genistein is more dynamic as an antioxidant than daidzein because of its third hydroxyl in the C-5 position (Ko 2014).

In conclusion, the starter culture of $S$. thermophilus FNCC40, L. bulgaricus FNCC41, and L. plantarum FNCC26 can grow well in edamame soymilk with cell density reaching $10^{9} \mathrm{CFU} / \mathrm{mL}$ after $24 \mathrm{~h}$ of fermentation. Fermented soymilk decreases the $\mathrm{pH}$ of soymilk from 6.7 to 3.3. The fermentation of edamame milk using these LABs strains increases the aglycone content of isoflavone, both daidzein, and genistein. The highest antioxidant activity of the soyghurt was observed in soymilk fermented with $S$. thermophilus FNCC40, which also has the highest genistein content (480.5 mAs), whereas soymilk fermented with $L$. bulgaricus FNCC41 did not have the highest antioxidative activity, despite having the highest level of daidzein (369.2 mAs). It may indicate the important role of genistein on the antioxidative activity of soygurts.

\section{REFERENCES}

Arena M, Caggianiello G, Russo P, Albenzio M, Massa S, Fiocco D, Capozzi V, Spano G. 2015. Functional Starters for Functional Yogurt. Foods 4 (1): 15-33. DOI: 10.3390/foods4010015.

Baglio E. 2014. Chemistry and Technology of Yoghurt Fermentation. Springer, Catania, Italy. DOI: 10.1007/978-3-319-07377-4

Boue SM, Carter-Wientjes CH, Shih BY, Cleveland TE. 2003. Identification of flavone aglycones and glycosides in soybean pods by Liquid Chromatography-Tandem Mass Spectrometry. J Chromatogr A, 991 (2003): 61-68. DOI: 10.1016/S0021-9673 (03)00209-7. 
Campos MDGR, Matos MP. 2010. Bioactivity of isoflavones: Assessment through a theoretical model as a way to obtain a Theoretical Efficacy Related to Estradiol (TERE). Intl J Mol Sci 11 (2): 480-491. DOI: 10.3390/ijms11020480.

Cheng KC, Wu JY, Lin JT, Liu WH. 2013. Enhancements of isoflavone aglycones, total phenolic content, and antioxidant activity of black soybean by solid-state fermentation with Rhizopus spp. Eur Food Res Technol 236 (6): 1107-13. DOI: 10.1007/s00217-013-1936-7.

Choi EJ, Kim GH. 2014. The antioxidant activity of daidzein metabolites, o-desmethylangolensin and equol, in HepG2 cells. Mol Med Rep 9 (1): 328-32. DOI: $10.3892 / \mathrm{mmr} .2013 .1752$

Choi YB, Kim KS, Rhee JS. 2002. Hydrolysis of soybean isoflavone glucosides by lactic acid bacteria. Biotechnol Lett 24 (24): 2113-16. DOI: 10.1023/A:1021390120400

Chun J, Kim GM, Lee KW, Choi ID, Kwon GH, Park JY, Jeong SJ, Kim SJ, Kim JH. 2007. Conversion of Isoflavone Glucosides to Aglycones in Soymilk by Fermentation with Lactic Acid Bacteria. 2007. J Food Sci 72 (2): 39-44. DOI: 10.1111/j.1750-3841.2007.00276.x.

Donkor ON, Henriksson A, Vasiljevic T, Shah NP. 2007. Original article proteolytic activity of dairy lactic acid bacteria and probiotics as determinant of growth and in vitro angiotensin-converting enzyme inhibitory activity in fermented milk. Lait 86 (2007): 21-38. DOI: 10.1051/lait.

$\mathrm{Fu} \mathrm{YH,} \mathrm{Zhang} \mathrm{FC.} \mathrm{2013.} \mathrm{Changes} \mathrm{in} \mathrm{isoflavone} \mathrm{glucoside} \mathrm{and} \mathrm{aglycone}$ contents of chickpea yoghurt during fermentation by Lactobacillus bulgaricus and Streptococcus thermophilus. J Food Process Preservation $37 \quad$ (5): 744-50. $\quad$ DOI: $10.1111 / \mathrm{j} .1745$ 4549.2012.00713x

Hammond BG, Jez JM. 2011. Impact of food processing on the safety assessment for proteins introduced into biotechnology-derived soybean and corn crops. Food Chem Toxicol 49 (4): 711-721. DOI: 10.1016/j.fct.2010.12.009.

Hasim, Astuti P, Falah S, Faridah DN. 2015. Bacillus subtilis Natto fermentation to improve aglycone isoflavones content of black soybean varieties Detam 2. Int Food Res J 22 (6): 2558-64.

Iovine B, Iannella ML, Gasparri F, Monfrecola G, Bevilacqua MA. 2011 Synergic effect of genistein and daidzein on UVB-induced DNA damage: An effective photoprotective combination. J Biomed Biotechnol 2011. DOI: 10.1155/2011/692846.

Isa JK, Razavi SH. 2017. Characterization of Lactobacillus plantarum as a potential probiotic in vitro and use of a dairy product (yogurt) as food carrier. Appl Food Biotechnol 4 (1): 11-18. DOI: 10.22037/afb.v4i1.13738.

Islam MA, Punt A, Spenkelink B, Murk AJ, van Leeuwen FXR, Rietjens IMCM. 2014. Conversion of major soy isoflavone glucosides and aglycones in vitro intestinal models. Mol Nutr Food Res 58 (3): 50315. DOI: $10.1002 / \mathrm{mnfr} .201300390$

James A. 2007. Edamame soybean development in Australia. Rural Industries Research and Development Corporation, Australian Government, Canberra.

Jayus J, Setiawan D, Giyarto C. 2018. Influence of Lactobacillus plantarum fermentation on functional properties of flour from jackfruit (Artocarpus heterophyllus Lamk.) seeds. Pertanika J Trop Agric Sci 41 (3): 1401-11.

Jayus J, Setiawan D, Giyarto C. 2016. Physical and chemical characteristics of jackfruit (Artocarpus heterophyllus Lamk.) seeds flour produced under fermentation process by Lactobacillus plantarum. Agric Agric Sci Procedia 9: 342-47. DOI: 10.1016/j.aaspro.2016.02.148.

Jooyandeh H. 2011. Soy products as healthy and functional foods Middle-East J Sci Res 7 (1): 71-80.

Ketudat JR, Cairns A. 2010. $\beta$-glucosidases. Cell Mol Life Sci (2010) 67 3389-3405. DOI: 10.1007/s00018-010-0399-2.

Ko KP. 2014. Isoflavones: Chemistry, analysis, functions and effects on health and cancer. Asian Pac J Cancer Prev 15 (17): 7001-7010. DOI: 10.7314/APJCP.2014.15.17.7001

Kobayashi M, Egusa S, Fukuda M. 2014. Isoflavone and protein constituents of lactic acid-fermented soy milk combine to prevent dyslipidemia in rats fed a high cholesterol diet. Nutrients 6 (12): 5704-23. DOI: 10.3390/nu6125704.

Lee CH, Yang L, Xu JZ, Yeung SYV, Huang Y, Chen ZY. 2005. Relative antioxidant activity of soybean isoflavones and their glycosides. Food Chem 90 (4): 735-41. DOI: 10.1016/j.foodchem.2004.04.034.

Lee M, Hong GE, Zhang H, Yang CY, Han KH. 2015. Production of the isoflavone aglycone and antioxidant activities in black soymilk using fermentation with Streptococcus thermophilus S10. Food Sci Biotechnol 24 (2): 537-544 (2015). DOI: 10.1007/s10068-015-00707.

Li C, Song J, Kwok LY, Wang J, Dong Y, Yu H, Hou Q, Zhang H, Chen Y. 2017. Influence of Lactobacillus plantarum on yogurt fermentation properties and subsequent changes during post fermentation storage. $\mathrm{J}$ Dairy Sci 100 (4): 2512-25. DOI: 10.3168/jds.2016-11864.

Li H, Yan L, Wang J, Zhang Q, Zhou Q, Sun T, Chen W, Zhang H. 2012. Fermentation characteristics of six probiotic strains in soymilk. Ann Microbiol 62 (4): 1473-83. DOI: 10.1007/s13213-011-0401-8.

Mebrahtu T, Mohamed A, Wang CY, Andebrhan T. 2004. Analysis of isoflavone contents in vegetable soybeans. Plant Foods Hum Nutr 59: 55-61.

Medjakovic S, Mueller M, Jungbauer A. 2010. Potential healthmodulating effects of isoflavones and metabolites via activation of PPAR and AhR. Nutrients 2 (3): 241-79. DOI: 10.3390/nu2030241.

Mentreddy SR, Mohamed AI, Joshee N, Yadav AK. 2002. Edamame: A nutritious vegetable crop. In: Janickand J, Whipkey A (eds.). Trends in New Crops and New Uses. ASHS Press, Alexandria, VA

Molina V, Médici M, de Valdez GF, Taranto MP. 2012. Soybean-based functional food with vitamin B 12-producing lactic acid bacteria. J Funct Foods 4 (4): 831-836. DOI: 10.1016/j.jff.2012.05.011.

Montero G, Günther G, Valdés K, Arriagada F, Morales J. 2018. An HPLC method for the determination of isoflavones and the evaluation of their antioxidant capacity in both homogeneous and microheterogeneous systems. J AOAC Intl 101 (1): 235-241. DOI: 10.5740/jaoacint.17-0104

Peng X, Guo S. 2015. Texture characteristics of soymilk gels formed by lactic fermentation: A comparison of soymilk prepared by blanching soybeans under different temperatures. Food Hydrocoll 43: 58-65. DOI: 10.1016/j.foodhyd.2014.04.034

Prasad LN, Shah NP. 2012. Conversion of isoflavone glycoside to aglycones in Soy Protein Isolate (SPI) using crude enzyme extracted from Bifidobacterium animalis $\mathrm{Bb} 12$ and Lactobacillus delbrueckii ssp. bulgaricus ATCC 11842. Intl Food Res J 19 (2): 433-439.

Rafii F. 2015. The role of colonic bacteria in the metabolism of the natural isoflavone daidzin to equol. Metabolites 5 (1): 56-73. DOI: 10.3390/metabo5010056.

Rekha CR, Vijayalakshmi G. 2010. Bioconversion of isoflavone glycosides to aglycones, mineral bioavailability and vitamin B complex in fermented soymilk by probiotic bacteria and yeast. J Appl Microbiol. DOI: 10.1111/j.1365-2672.2010.04745.x.

Rigo AA, Dahmer AM, Steffens C, Steffens J, Carrão-Panizzi. 2015. Characterization of soybean cultivars genetically improved for human consumption. Int J Food Eng 1 (1): 1-7. DOI: 10.18178/ijfe.1.1.1-7.

Shah NP 2000. Probiotic bacteria: selective enumeration and survival in dairy food. J Ethnic Foods 2 (1): 2-7. DOI: 10.3168/jds.S0022-0302 (00)74953-8.

Sirilun S, Chaiyasut C, Kesika P, Peerajan S, Sivamaruthi BS. 2017a. Screening of Lactic Acid Bacteria with immune modulating property, and the production of lactic acid bacteria mediated fermented soymilk. Nat J Physiol Pharm Pharmacol 7 (12): 1397-1405. DOI: 10.5455/njppp.2017.7.0933926092017.

Sirilun S, Sivamaruthi BS, Kesika P, Peerajan S, Chaiyasut C. 2017b. Lactic acid bacteria mediated fermented soybean as a potent nutraceutical candidate. Asian Pac J Trop Biomed 7 (10): 930-36. DOI: 10.1016/j.apjtb.2017.09.007

Song X, Xue Y, Wang Q, Wu X. 2011. Comparison of three thermostable $\beta$-glucosidases for application in the hydrolysis of soybean isoflavone glycosides. J Agric Food Chem 59 (5): 1954-61. DOI: $10.1021 /$ jf1046915

Tsuda H, Shibata E. 2017. Bioconversion of daidzin to daidzein by lactic acid bacteria in fermented soymilk. Food Sci Technol Res 23 (1): 157-62. DOI: 10.3136/fstr.23.157.

U.S. Department of Agriculture. 2008. USDA Database for the Isoflavone Content of Selected Foods. In Release 2.0. U.S. Department of Agriculture Agricultural Research Service Beltsville Human Nutrition Research Center, U.S. Department of Agriculture. http://www.ars.usda.gov/nutrientdata.

Wei QK, Chen TR, Chen JY. 2007. Using of Lactobacillus and Bifidobacterium to product the isoflavone aglycones in fermented soymilk. Intl J Food Microbiol 117 (2007): 120-124. DOI: DOI: 10.1016/j.ijfoodmicro.2007.02.024. 